\title{
Ареалы высотно-зональных лесов Тувы
}

\section{Areas of altitudinal zonal forests of Tuva}

\author{
Макунина Н. И., Егорова А. В., Писаренко О. Ю. \\ Makunina N. I., Egorova A. V., Pisarenko O. Yu.
}

Центральный сибирский ботанический сад СО РАН, г. Новосибирск, Россия. E-mail: natali.makuпina@mail.ru

Central-Siberian botanical garden, Novosibirsk, Russia

\begin{abstract}
Peфepam. Тува - горный регион со сложной мозаикой распределения рельефа, климатических факторов и растительности. Она расположена в пределах трех биоклиматических секторов (семигумидного, семиаридного, аридного) и одного переходного района (аналог семиаридного сектора в семигумидном). Высотно-зональные леса - это коренные леса, распространенные на горных плакорах в лесном и лесостепном поясах. В Туве их разнообразие представлено семи ассоциациями флористической классификации. Потенциальные ареалы этих ассоциаций построены с помощью программы MaxEnt на основе 61 растрового изображения, содержащего информацию об орографических, климатических и биоклиматических параметрах. Данными о локалитетах послужили GPS-координаты 158 геоботанических описаний зональных лесов, выполненных Н. И. Макуниной. Потенциальные ареалы ассоциаций высотно-зональных лесов подтверждают концепцию биоклиматического деления Тувы.
\end{abstract}

Ключевые слова. Ареал, ассоциация, высотно-зональная растительность, леса, Тува.

Summary. Tuva is a mountainous region with a complex mosaic of relief, climate and vegetation distribution. It is located within three bioclimatic sectors (semi-humid, semi-arid, arid) and one transition region (analogue of semiarid sector in semi-humid). Altitudinal zonal forests are native forests on mountain plakors in forest and forest-steppe altitudinal zones. In Tuva, their diversity is described as seven associations of floristic classification. Potential areas of associations were built using MaxEnt program based on 61 raster images comprising information about orographic, climatic and bioclimatic parameters. GPS-coordinates of 158 geobotanical descriptions of zonal forests made by N. I. Makunina became the data on the localities. Potential areas of altitudal zonal forests support concept of bioclimatic partition of Tuva.

Key words. Altitudinal zonal vegetation, area, association, forests, Tuva.

\section{Введение}

Тува находится в географическом центре Азии. На этой территории расположены высокогорные, среднегорные хребты и плоскогорья, разделенные межгорными котловинами. Гидрографическая сеть принадлежит, главным образом, верхней части бассейна Енисея, в меньшей степени она относится к бассейнам бессточных впадин Центральной Азии. Водоразделом являются хребты Танну-Ола, отделяющие основную часть Тувы от внутренних бессточных бассейнов северо-западной Монголии.

Климат сильно различается в разных частях Тувы. В целом для Тувы характерен резко континентальный климат, обусловленный ее положением в центре материка, удаленностью от океанов, орографической изолированностью, близостью пустынных ландшафтов Центральной Азии. Преобладание в зимнее время антициклонального режима вызывает стратификацию холодного воздуха в депрессиях (Ефимцев, 1957) и снижение зимних температур до $-30--40{ }^{\circ} \mathrm{C}$. Стекание холодного воздуха в межгорные котловины вызывает зимой в окружающих горах температурные инверсии, поэтому в октябре и ноябре там холоднее, чем в котловинах, а с декабря по март на несколько градусов теплее. Средняя температура самого теплого месяца - июля - в котловинах составляет $18-20^{\circ} \mathrm{C}$. Лето в горах более холодное и короткое: в нижней полосе среднегорий (1400 м) средняя температура июля понижается до $+13-+15^{\circ} \mathrm{C}$. Основная часть осадков в Туве выпадает летом, как правило, в форме ливней. Осадки, как 
и другие климатические показатели, на территории Тувы распределяются неравномерно: среднегодовое количество осадков варьирует от 200 мм в котловинах до 800 мм в горах.

Территория Тувы относится к Алтае-Саянской горной области, распределение ее растительности подчиняется законам высотной поясности. Спектр высотных поясов, а также высотные границы каждого из них отличаются в разных частях Тувы. Группы районов со сходными высотными отметками и сходным набором растительных сообществ называют биоклиматическими секторами (Макунина, 2016). Тува расположена в пределах трех биоклиматических секторов и одной переходной группы биоклиматических районов (рис. 1).

Семигумидный сектор включает в себя Центральную и Восточную Туву. Он охватывает и горные хребты, и межгорные котловины. Базисный степной пояс ((600) 800-1000 м) занимает днища Турано-Уюкской и Улуг-Хемской межгорных котловин. Нижние части горных макросклонов, спускающихся к котловинам, относятся к лесостепному поясу (1000-1400 м). Высоты от 1400 до (1800) 2000 м занимает лесной (таежный) пояс. Выше (1800) 2000 м расположен высокогорный пояс.

К семиаридному сектору относится южная часть Тувы. Базисным является степной пояс: степи покрывают днище Убсу-Нурской котловины и склоны гор до 1500 м. Высоты 1500-1800 м занимает горная лесостепь. Неширокий таежный пояс (1800-2200 м) на южных склонах нередко прерывается луговыми степями. Выше 2200 м лежит высокогорный пояс.

Аналог семиаридного сектора. Этот тип высотной поясности характерен для Западной Тувы. Явления аридизации проявляются в первую очередь в том, что высотные отметки границ поясов увеличиваются: верхняя граница степного пояса в семигумидном секторе составляет 1000 м, в аналоге семиаридного сектора - (1200) 1400 м, лесостепного - 1400 и (1400) 1600 м соответственно. Лесной пояс образует сплошную полосу в высотном диапазоне (1400) 1600-2000 м.

Аридный сектор (Юго-Западная Тува). Базисным является подпояс опустыненных степей. Нижние и средние ступени гор до высот 2200-2400 м занимает собственно степной пояс. Лесной пояс отсутствует, однако на теневых макросклонах горных хребтов в верхней части степного пояса (2100 2400 м) встречаются лесостепные ландшафты, образующие фрагментарный лесостепной подпояс. Вершины гор занимает высокогорный пояс.

Леса широко распространены в двух высотных поясах: лесном и лесостепном. Зональными мы называем коренные леса, распространенные на горных плакорах - пологих склонах и на склонах средней крутизны в каждом из поясов. Разнообразие зональных лесов Тувы представлено в продромусе.

Класс Brachypodio pinnati-Betuletea pendulae Ermakov, Korolyuk et Lashchinsky 1991

Порядок Carici macrourae-Pinetalia sylvestris Ermakov, Korolyuk et Lashchinsky 1991

Союз Vicio unijugae-Pinion sylvestris Ermakov, Korolyuk et Lashchinsky 1991

Acc. Calamagrostio pavlovii-Laricetum sibiricae Ermakov in Ermakov et al.2000

Класс Rhytidio rugosi-Laricetea sibiricae Korotkov et Ermakov 1999

Порядок Carici hediformis-Laricetalia sibiricae Ermakov in Ermakov et al. 1991

Союз Carici pediformis-Laricion sibiricae Ermakov in Ermakov et al. 1991

Acc. Anemono sylvestris-Laricetum sibiricae Ermakov 1995

Acc. Artemisio santolinifoliae-Laricetum sibiricae Makunina 2011

Порядок Festuco ovinae-Laricetalia sibiricae Korotkov et Ermakov ex Ermakov et al. 2000

Союз Pachypleuro alpini-Laricion sibiricae Ermakov 2000 in Ermakov et al. 2000

Acc. Artemisio rupestris-Laricetum sibiricae Makunina 2014

Класс Vaccinio-Piceetea Br.-B1. in Br.-B1. et al. 1939

Порядок Lathyro humilis-Laricetalia cajanderi Ermakov, Cherosov et Gogoleva 2002

Союз Rhododendro daurici-Laricion gmelinii Ermakov, Cherosov et Gogoleva 2002

Acc. Vaccinio vitis-idaeae-Betuletum pendulae ass. prov.

Acc. Aegopodio alpestris-Laricetum sibiricae ass. prov.

Acc. Vaccinio vitis-idaeae-Laricetum sibiricae Hilbig (1987) 1990 


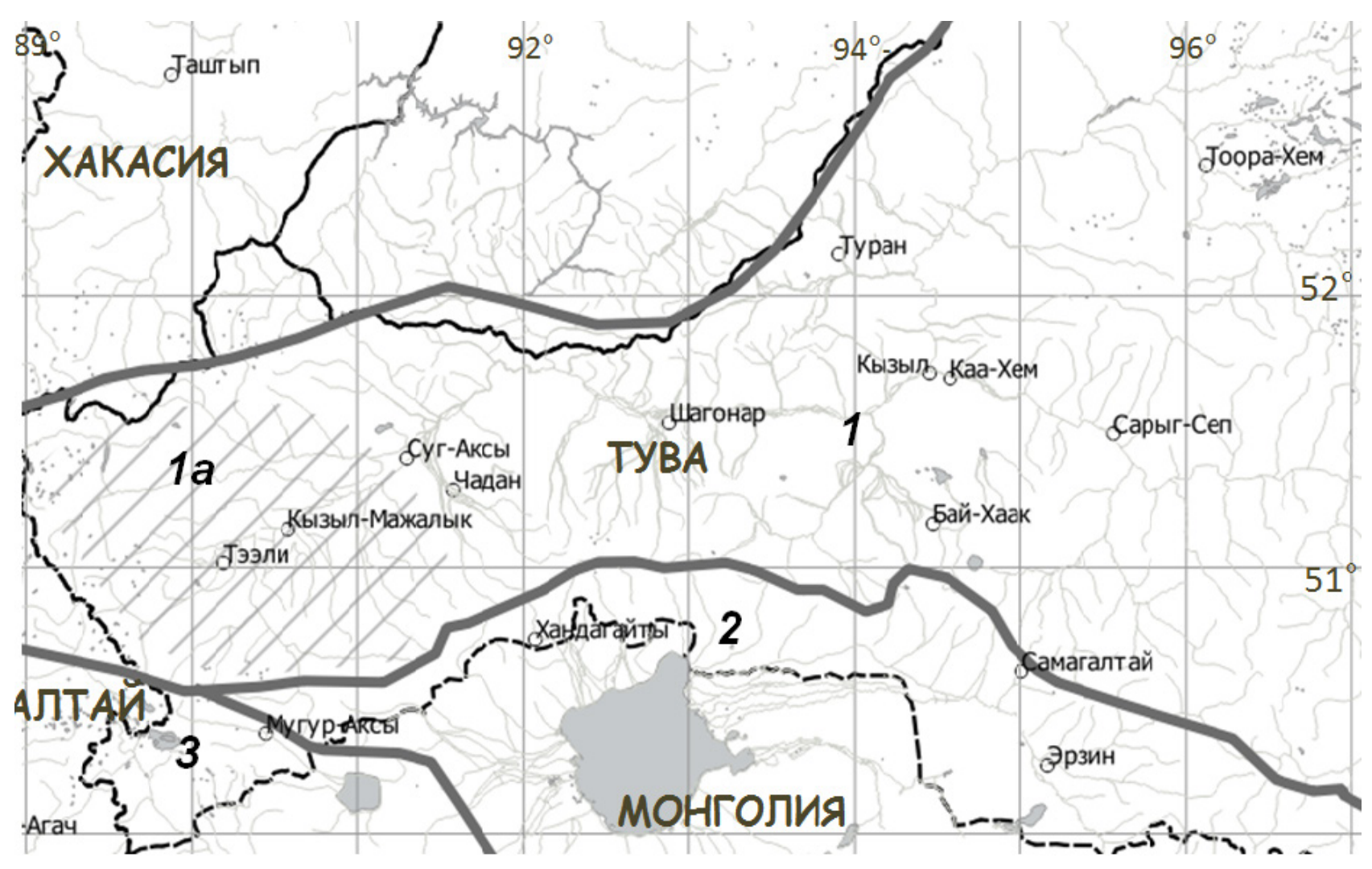

Рис. 1. Биоклиматическое районирование Тувы. Биоклиматические секторы: 1 - семигумидный; 1a - аналог семиаридного сектора в семигумидном; 2 - семиаридный; 3 - аридный.

Флористическая классификация четко определяет флористические особенности ее основных единиц - ассоциаций, однако их ареалы, очерченные исходя из ограниченной выборки конкретных описаний, в большинстве случаев субъективны, поскольку напрямую зависят от личного опыта исследователя. Одной из возможных вариантов преодоления ограничений - построение вероятностного потенциального ареала.

\section{Материалы и методы}

В работе использованы 158 геоботанических описаний Н. И. Макуниной с GPS-координатами, выполненные в период с 2002 по 2018 гг.

Для построения модели использовалась программный пакет MaxEnt, в основу которого положен метод максимальной энтропии (Phillips et al., 2006). В настоящее время он является одним из эффективных методов моделирования распределения видов, когда в распоряжении исследователя есть только данные о присутствии вида. Графическое отображение результатов осуществлено в программа NextGIS QGIS version: 18.10.0. На территорию Алтае-Саянской горной области и прилегающую часть Западно-Сибирской равнины были созданы растровые слои разрешением 90м-пиксель. Для ограничения размера потенциального ареала использовано максимально доступное количество слоев. Они характеризуют распределение следующих показателей:

- биоклиматические переменные BIOCLIM (19 растров),

- месячные средние температуры (12 растров),

- месячное количество осадков (12 растров),

- месячная солнечная радиация (12 растров),

- гипсометрические показатели (высота, экспозиция, крутизна) (3 растра),

- индексы NDVI (май, июль, сентябрь) (3 растра).

Ареал ассоциаций представляет ее потенциальный ареал при пороговом значении вероятности 0,5 . 


\section{Результаты и обсуждение}

Мы построили модели потенциальных ареалов 7 зональных ассоциаций; 3 - лесного пояса и 4 - лесостепного. Для оценки качества модели в программе используется показатель AUC - оценка способности модели указывать присутствие вида в той точке растра, где он с большой вероятностью должен находиться (максимальное значение AUC равно 1,0). Для всех моделей он превышает 0,99, что характеризует модели как отличные.

Лесной пояс. В лесном поясе Тувы коренными являются таежные леса трех ассоциаций класса Vaccinio-Piceetea. Полученные данные об их потенциальных ареалах подтверждают секторные границы и адекватно отражают существующее распределение лесов.

Таежные травяные леса асc. Vaccinio vitis-idaeae-Betuletum pendulae. В сложении их древостоя в равной мере принимают лиственница, кедр, береза повислая и ель. В густом травяном ярусе содоминируют таежные виды и виды мелколиственных лесов. Негустой моховой ярус сложен гигромезофильными мхами. Ареал ассоциации охватывает Центральную и Восточную Туву, расположенные в семигумидном биоклиматическом секторе (рис. 2). На севере потенциальный ареал занимает прилегающую часть гумидного сектора, южная граница ареала совпадает с границей семиаридного сектора. Четко прослеживается западная граница, отделяющая основную часть семигумидного сектора.

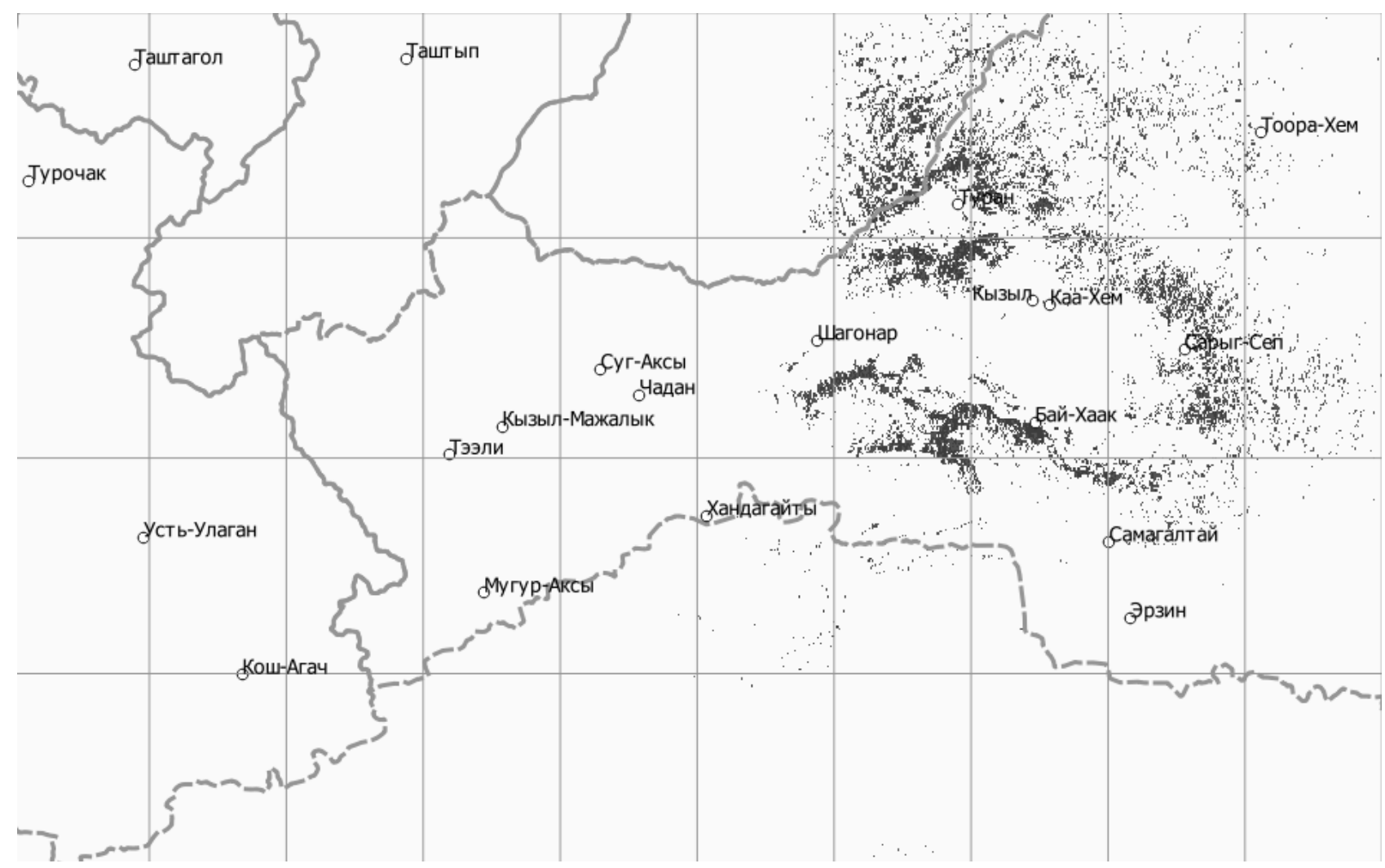

Рис. 2. Потенциальный ареал асc. Vaccinio vitis-idaeae-Betuletum pendulae.

Таежные травяные и брусничные леса acc. Aegopodio alpestris-Laricetum sibiricae. В сложении древостоя лесов в равной мере участвуют лиственница, кедр и ель. В густом травяно-кустарничковом ярусе содоминируют таежные и горно-лесные виды. Густой моховой ярус сложен гигромезофильными мхами. Основная часть ареала ассоциации расположена в Западной Туве (аналог семиаридного сектора), восточная граница ареала ассоциации совпадает с его восточной границей (рис. 3). На западе ареал выходит за пределы Тувы, охватывая сопредельные части Юго-Восточного Алтая. Южная часть ареала лежит в пределах западной части гор Южной Тувы (семиаридный сектор). 


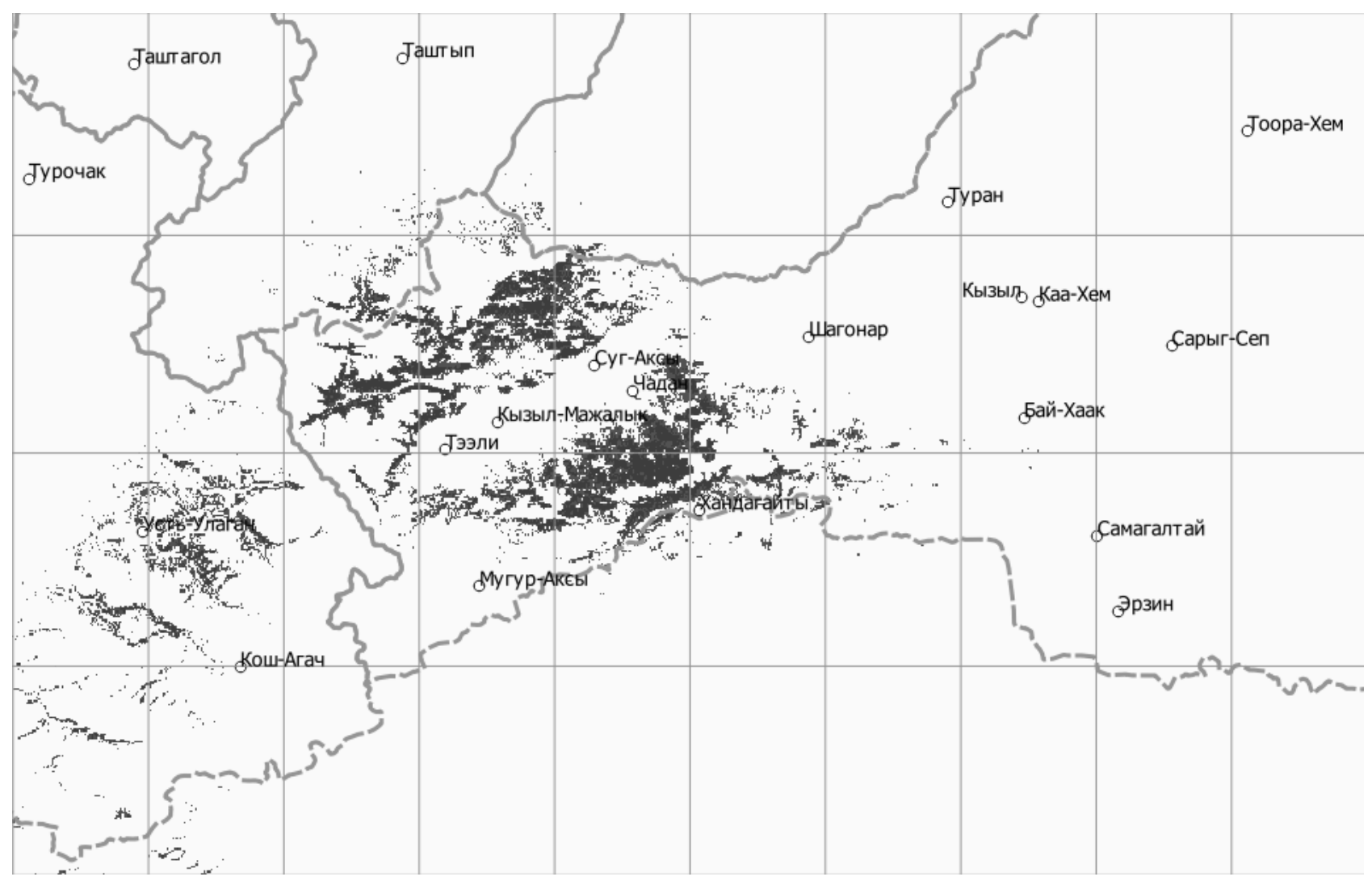

Рис. 3. Потенциальный ареал асc. Aegopodio alpestris-Laricetum sibiricae.

Таежные брусничные и зеленомошные леса acc. Vaccinio vitis-idaeae-Laricetum sibiricae. Древостой образуют лиственница и кедр, в примеси встречается ель. В негустом травяно-кустарничковом ярусе доминирует брусника. Густой мохово-лишайниковый ярус образуют преимущественно гигромезофильные мхи. Основная часть ареала расположена в горах Южной Тувы (семиаридный биоклиматический сектор), фрагменты ареала присутствуют в Западной Туве (аналог семиаридного сектора) (рис. 4).

В лесостепном поясе коренными являются леса одной ассоциации класса Brachypodio pinnatiBetuletea pendulae и двух ассоциаций класса Rhytidio rugosi-Laricetea sibiricae.

Подтаежные травяные леса асc. Calamagrostio pavlovii-Laricetum sibiricae. Древостой образован лиственницей и березой повислой, в густом травостое преобладают виды мелколиственных лесов и горно-лесные виды. Моховой ярус не выражен.

Ареал ассоциации ограничен Центральной Тувой (семигумидный сектор), четко прослеживается его западная граница (рис. 5).

Лесостепные остепненно-травяные леса асc. Anemono sylvestris-Laricetum sibiricae. Древостой сложен преимущественно лиственницей, в густом травостое преобладают лугово-степные виды, моховой ярус практически отсутствует. Ареал ассоциации охватывает лесостепной пояс Западной, Центральной и Южной Тувы и расположен в семигумидном и семиаридном секторах (рис. 6). Леса ассоциации обычны на пологих склонах и склонах средней крутизны с развитым почвенным покровом.

Лесостепные остепненно-травяные леса acc. Artemisio santolinifoliae-Laricetum sibiricae. Древостой сложен лиственницей, в травостое преобладают лугово-степные виды, моховой ярус образуют ксеромезофильные мхи. Основное отличие экологических ареалов предыдущей и описываемой 


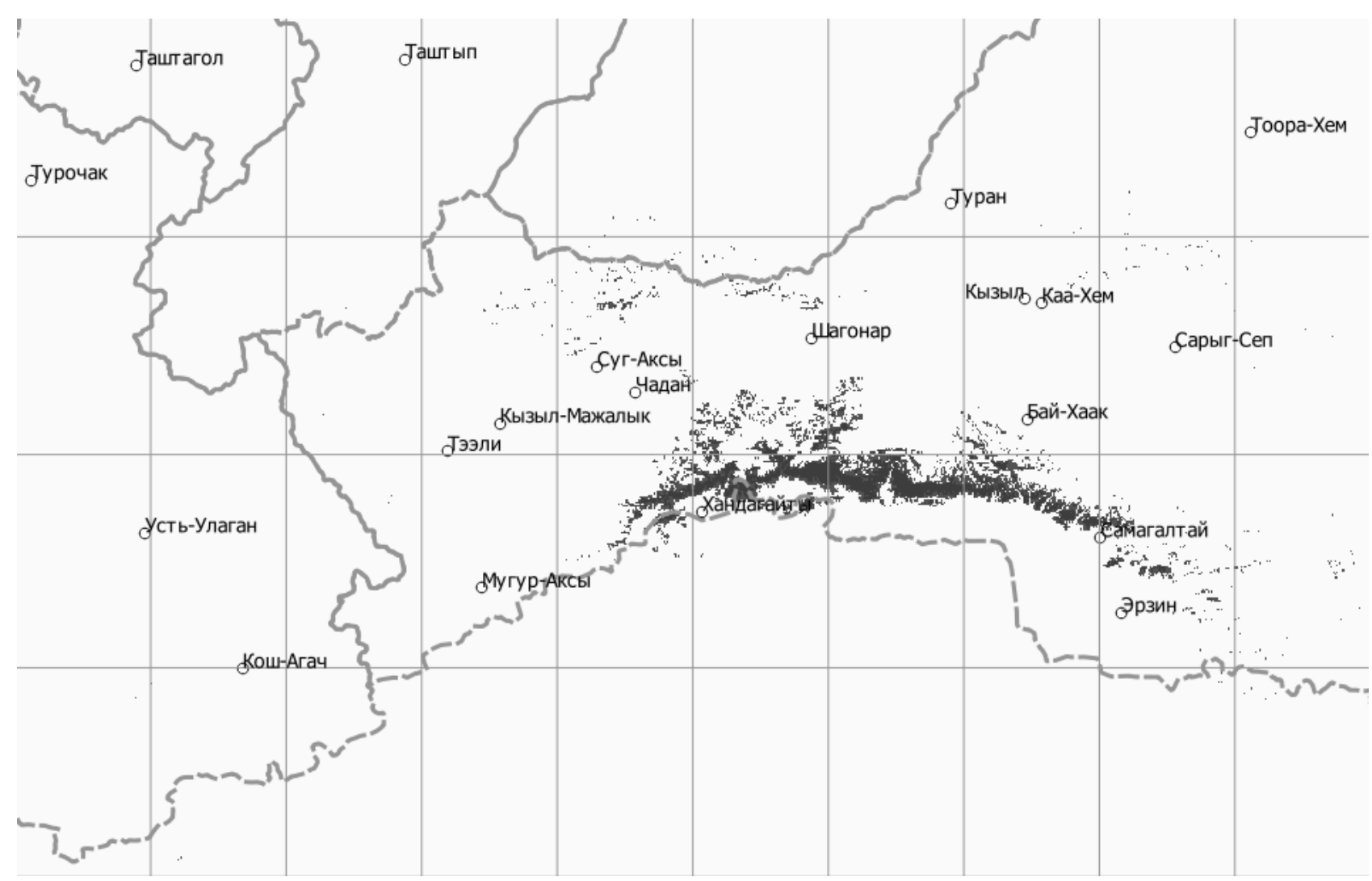

Рис. 4. Потенциальный ареал асc. Vaccinio vitis-idaeae-Laricetum sibiricae.

ассоциаций состоит в крутизне склонов: леса последней встречаются на крутых склонах с выходами камней. Ареал ассоциации состоит из двух частей (рис. 7), одна из которых охватывает горы Южной Тувы (семиаридный сектор), другая - горы Западной Тувы (аналог семиаридного сектора).

В лесостепном подпоясе степного пояса аридной Юго-Западной Тувы встречаются псевдотаежные лиственничные леса acc. Artemisio rupestris-Laricetum sibiricae (класc Rhytidio rugosi-Laricetea sibiricae). Древостой сложен исключительно лиственницей, травяной ярус образуют виды трех высотно-поясных групп: лесостепной, лесной и высокогорной. В мохово-лишайниковом ярусе в одинаковой мере представлены гигромезофильные мхи, ксеромезофильные мхи и лишайники. Леса ассоциации имеют узкий потенциальный ареал, совпадающий с реально выявленным (рис. 8).

Таким образом, потенциальные ареалы ассоциаций высотно-зональных лесов подтверждают биоклиматическое деление территории Тувы.

\section{Заключение}

Использование подходов моделирования ареалов ассоциаций, реализованных с помощью программы Maxent позволило экстраполировать фрагментарные данные о конкретных локалитетах сообществ ассоциаций на территории, подробно не изученные в этом отношении и выявить участки, аналогичные по биоклиматическим, гипсометрическим и другим показателям.

Благодарности. Работа выполнена в рамках государственного задания Центрального сибирского ботанического сада СО РАН (№ гос. регистрации АААА-А17-117012610052-2), а также при частичной финансовой поддержке Российского фонда фундаментальных исследований (проект № 18-0400822). 


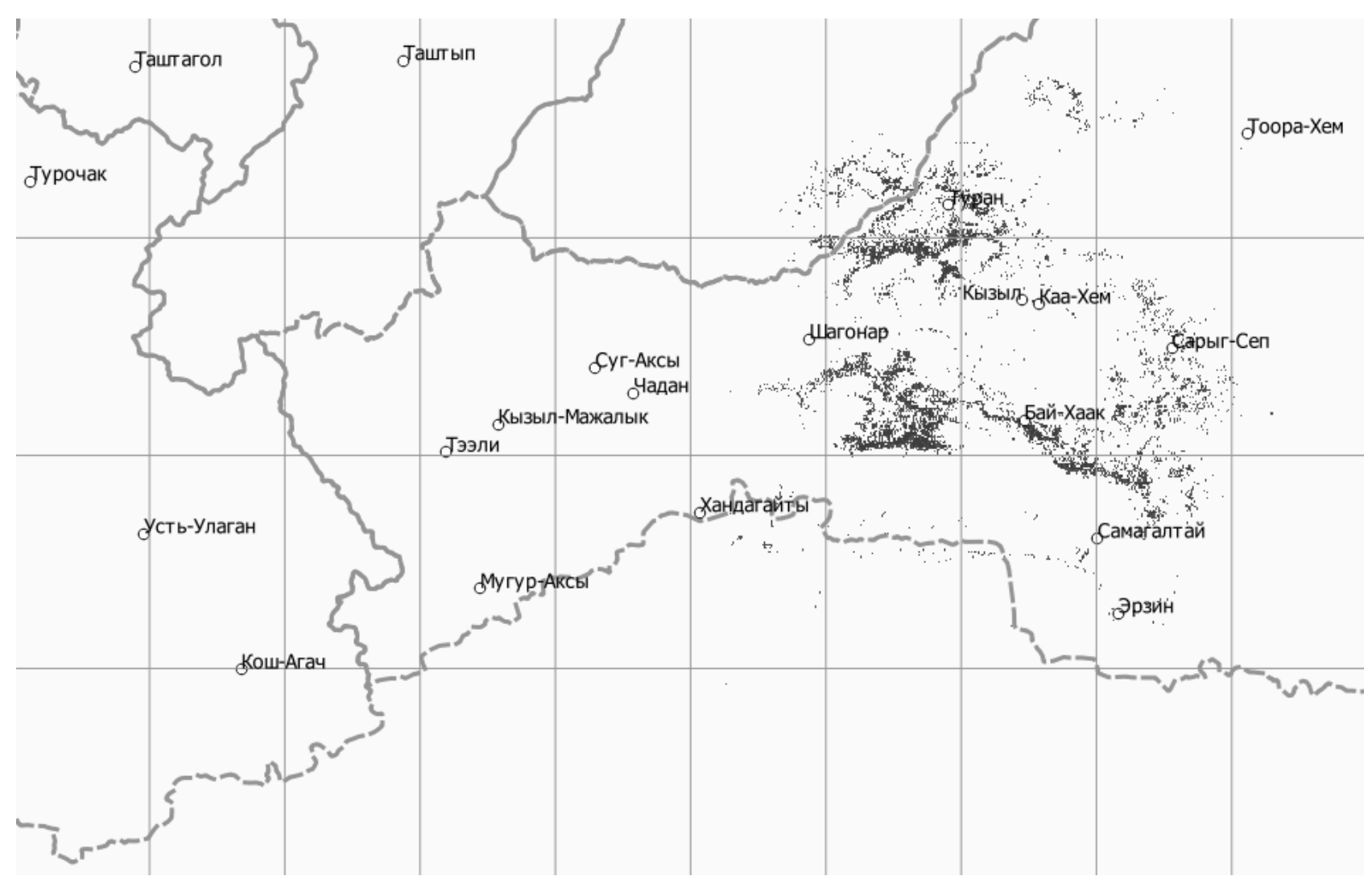

Рис. 5. Потенциальный ареал асc. Calamagrostio pavlovii-Laricetum sibiricae.

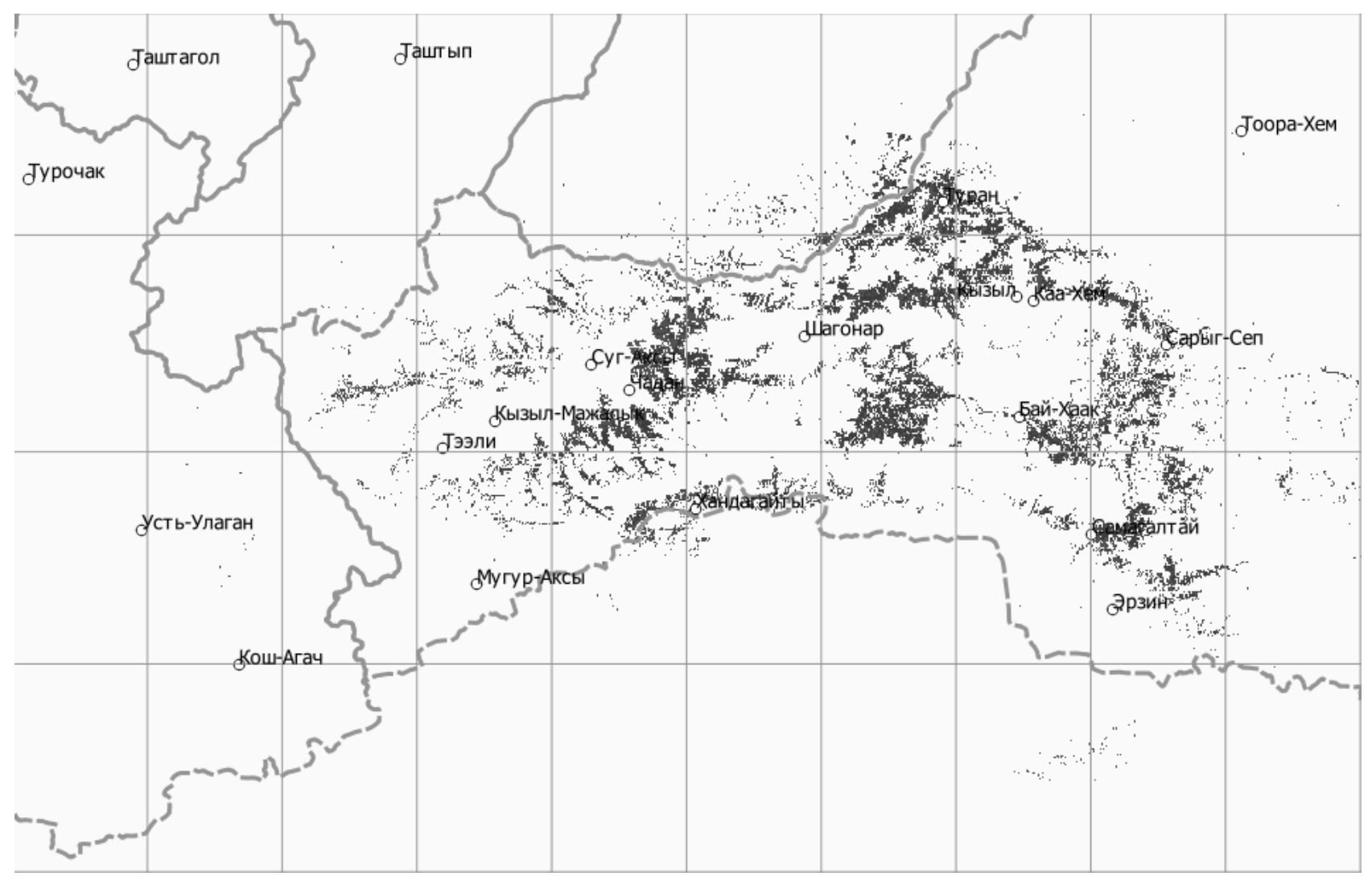

Рис. 6. Потенциальный ареал асc. Anemono sylvestris-Laricetum sibiricae. 


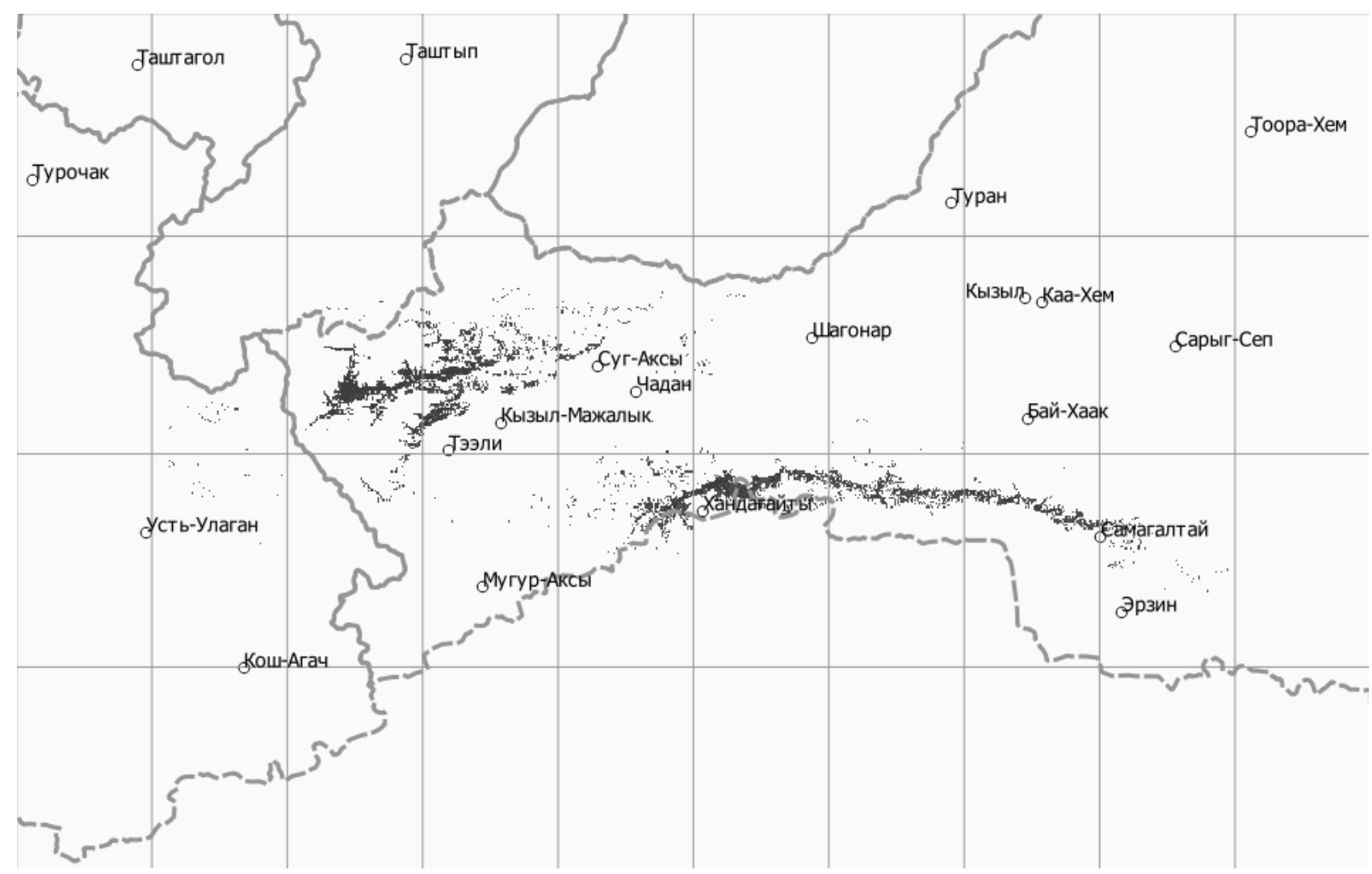

Рис. 7. Потенциальный ареал acc. Artemisio santolinifoliae-Laricetum sibiricae.

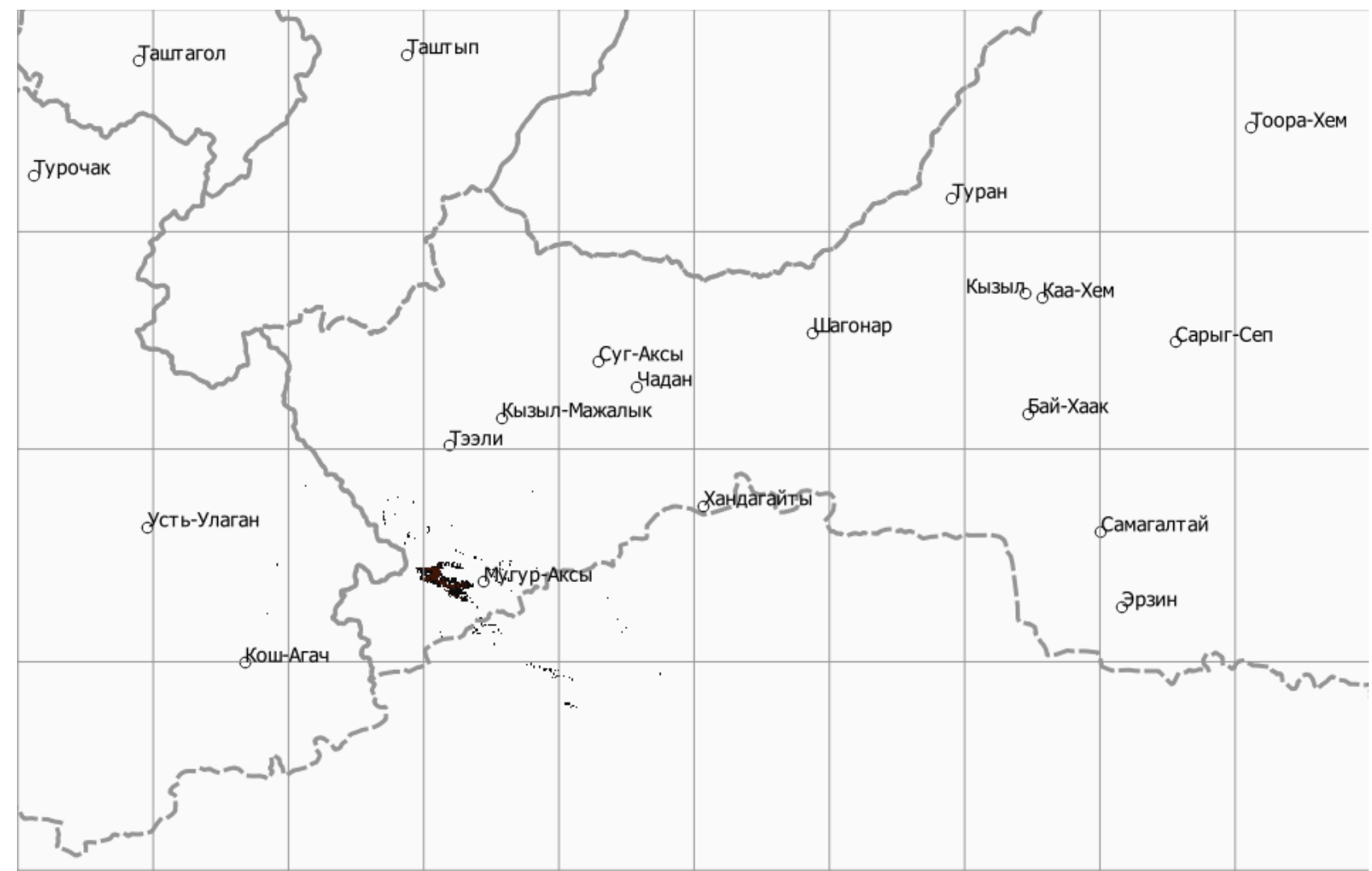

Рис. 8. Потенциальный ареал асc. Artemisio rupestris-Laricetum sibiricae. 


\section{ЛИТЕРАТУРА}

Eфимцев $\boldsymbol{E}$. $\boldsymbol{A}$. Климатический очерк // Природные условия Тувинской автономной области. - М., 1957. - С. 46-65.

Макунина Н. И. Ботанико-географическая характеристика лесостепи Алтае-Саянской горной области // Сибирский экологический журнал, 2016. - № 3. - С. 405-413.

Phillips S. J., Anderson R. P., Schapire R. E. Maximum entropy modeling of species geographic distributions // Ecological Modelling, 2006. - Vol. 190, №3-4. - P. 231-259. 